\title{
The opportunity of stimulation measures for the Romanian migrants returni
}

\author{
Dorel Ailenei ${ }^{1}$, Amalia Cristescu $^{2}$ and Andrei Hrebenciuc ${ }^{3}$ \\ ${ }^{1,3}$ Bucharest Academy of Economic Studies, Faculty Economics \\ Bucharest, Romania \\ ${ }^{2}$ Bucharest Academy of Economic Studies, Faculty Economics \\ Bucharest, Romania and National Scientific Research Institute for Labour and Social Protection \\ Bucharest, Romania
}

Correspondence should be addressed to: Dorel Ailenei; dorel_ailenei@yahoo.com

Received date: 9 September 2013; Accepted date: 22 February 2015; Published date: 19 August 2015

Academic Editor: Daniela Mardiros

Copyright @ 2015. Dorel Ailenei, Amalia Cristescu and Andrei Hrebenciuc. Distributed under Creative Commons CC-BY 4.0

\begin{abstract}
The removing of the last remaining barriers on the Bulgarian and Romanian workers' access to the single market of the EU labour created a wave of unrest in Western Europe concerning the destabilization flows of immigrants that might affect the labour markets and the social security budgets. But the origin countries of emigrants have fears about the balance of domestic labour markets, and also economic growth. Following these arguments, the governments prepare packages of measures for stimulating the return of emigrants. The authors of this paper consider the need for a well-documented analysis of the opportunity cost of labour exports based on system variables. However, before any analysis the most important step of grounding action programs would be to consult the immigrants. It is this essential aspect that is addressed in this paper based on a survey conducted on a sample of 1,200 Romanian workers in Italy. The choice was motivated by the fact that Italy, along with Spain, is the most important target for Romanian immigrants' preferences due to the linguistic affinities (Latin origin), cultural, historical and ethno genesis. The authors have proposed to determine correlations based on testing, with logistic regression, intensity factors that could influence the intention of the Romanian workers in Italy to return home, namely the factors that would cause them to remain in this country.
\end{abstract}

Keywords: migration, labour force, motivation intensity, intentions to return

\section{Introduction}

With the rise of globalization and democratic transformations in more developing countries the migration flows have taken a new scale at the global level. At the European level the increased migration flows were supported by two main factors: the collapse of communism in Central and Eastern European Countries (CEEC) and then, by the integration of these countries in the European Union. Beyond the net benefits for workers and destination countries there is a series of

Cite this Article as: Dorel Ailenei, Amalia Cristescu and Andrei Hrebenciuc (2015)," The opportunity of stimulation measures for the Romanian migrants return ", Journal of Eastern Europe Research in Business and Economics , Vol. 2015 (2015), Article ID 181957, DOI: 10.5171/2015.181957 
controversies related to immigrants pursuing fraudulent objectives in their labor market integration. On the other hand, migrants' countries of origin reclame the significant loss of labor force that negatively affects internal labor markets and economic growth. Under these conditions tensions frequently occur concerning new immigration flows from CEEC's into old E.U.'s Member States.

However, beyond the tensions over the economic policy, what matters is the behavioral motivations of emigrants people who strive to become free. From this perpective, the economic literature proposes a number of theories dedicated to the phenomenon of migration, from which the authors have retained those that might be relevant to the conducted research.

\section{The Keynesian Theory}

The Keynesian economic theory believes that labor supply depends also on the nominal wage, not just on the real one. This distinction stems from the different views on the role that money plays in the economy. From this prespective, potential emigrants are attracted into the regions with higher nominal wages. Furthermore, intentions to migrate again or deliver remittances enhance the nominal wage level compared to the actual one. Therefore, it may not be a new balance as the neoclassical theory states, but a decrease in the unemployment gap (Jennissen, 2007).

\section{The neoclassical theory of human capital}

The neoclassical theory is supported by followers of the Chicago School of Economics (1950), including Sjaastad, Schultz, Becker, Bowles, Bowman, Myers. This theory approaches the migration process in terms of human capital investmensts and considers that there are big costs in the beginning in order to get further benefits for a longer period of time. It is considered that, if the expected revenues exceed the costs, the person will choose to move. Otherwise, there is not a decision favorable for migration, even if the potential gains from the destination are much more incentives than the ones from the origin country. (McConnell et al., 2010).

\section{The Search Theory (job-matching)}

Jackman and Savouri (1992) argue that individuals will migrate after getting a job at the destined location, unlike the traditional approach (neoclassical theory) which considers that migration occurs before finding a job at the destination. This theory studies the macroeconomic outcome when one or more individuals interact. Before taking a decision, an individual must know the available opportunities. Further more, there are two distinct phases in such a decision: first the idividual estimates the migration costs and anticiped benefits for making a favorable decision, or not; then there is an evaluation of the new particular job that will be taken.

\section{Theory of rejection factors - attraction or push-pull}

This theory considers that migration is governed by a "rejection-attraction" process, the unfavorable conditions in their original location "forcing" people to emigrate, while the favorable conditions in the destination location attracts the immigration flows. The rejection factors (internal ones) could be caused by: an insufficient income level, a high level of unemployment, low living standards, unfavorable climatic conditions, dictatorial politic regime, religous or interetnic conflicts etc. The attraction factors (external ones) are considered to be: more and better jobs, high living standards, freedom and a democratic political regime, favorable opportunities for career development, health care quality, better conditions for the education of children etc.

\section{The Theory of social networks}

This theory addresses the phenomenon from the mass migration perception, considering that in the case of large migration flows there are functional networks that support the migration process. Such networks involve interpersonal relationships between origin and destination populations based on kinship, ethnicity, or friendship. The „old” 
emigrants provide "new" ones information about the local labor market, existing facilities or provide temporary accommodation (Fawcett, 1989). Bauer and Zimmermann (1995) consider that the migration process is self-propagating due to the fact that the costs and risks become smaller due to these cohorts, or, in other words, migration generates more migration.

\section{The Tiebout theory}

The theory states that citizens are free to choose the community they want to live when taking into account the available information. There is an optimal community that maximizes individual utility and ensures the best public services. However, rational communities are trying to stop the bad migration flows and try to achieve an optimum size (Tiebout, 1956).

\section{The empirical analysis}

This paper is based on a survey conducted among Romanian immigrants in Italy by the National Research Institute for Labour and Social Protection. It started from the fact that the main destinations of migration flows from Romania are Italy and Spain, which are also Latin countries like Romania. In addition, in the case of Italy, the historical sources and legends claim there are common roots between Italy and Romania.

The sample consists of 1,200 Romanian workers located in four Italian regions: Lazio, Piemonte, Lombardia and Puglia. Data were collected during April-May 2011.
The research had the following objectives:

- Investigating the characteristics of labour supply among Romanian workers / or persons seeking employment in Italy;

- Analysis of the expectations and needs of specific employment services among Romanian workers / people looking for a job in Italy;

- Develop policy recommendations to support the return of Romanian emigrant workers.

- Adjusting the statistic information regarding the number, structure, characteristics and location of Romanian emigrants.

- Investigating the trend of return migration from Italy to Romania and its determinants;

\section{The characteristics of migration flows}

Thus, as a confirmation of the hypothesis of common historical roots of Italians and Romanians, $71 \%$ of respondents said they speak and read easily in Italian, although this language is rarely present in the curriculum programs of secondary education. Only $4.9 \%$ of them said they speak and understand little in Italian language. Interestingly, the gender structure of the flows of foreign immigrants is significantly positive for women (57\% women and approx. 43\% men). Another feature is given by the dominance of Romanian youth in the flows of migrants $(32.1 \%$ - $18-30$ years and $35.7 \%$ - 30-40 years) as in Figure 1 


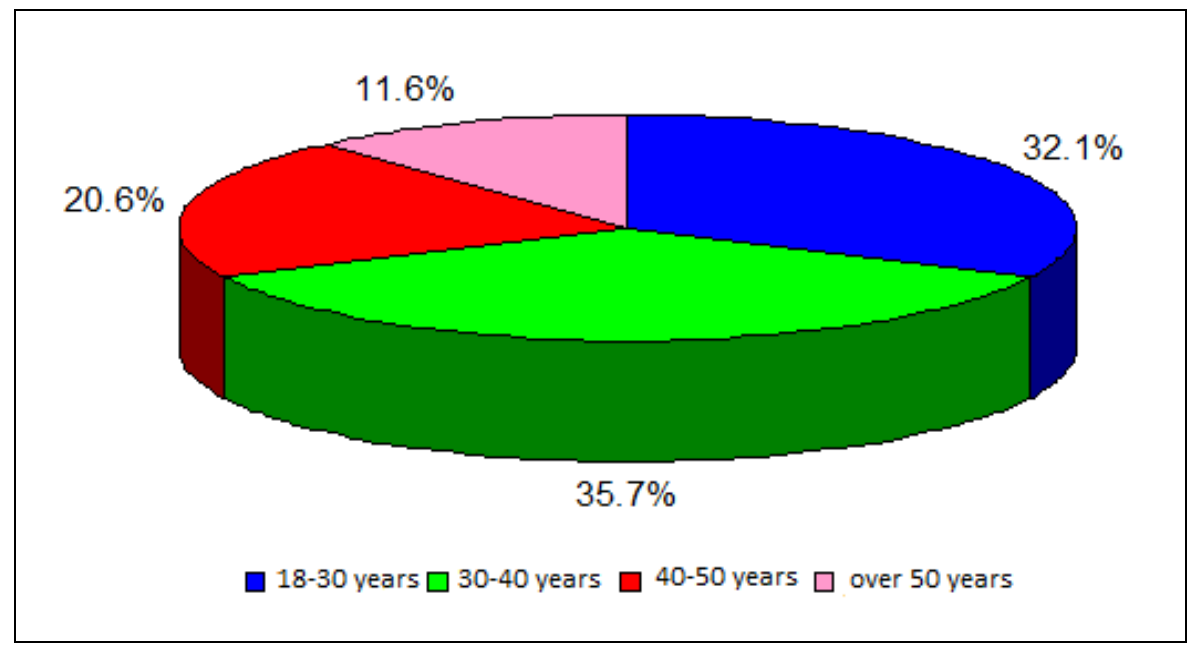

Figure1: Age Distribution of migrants (\%)

Moreover, the overwhelming majority (78.9\%) of Romanian immigrants in Italy have secondary education, and about $11.1 \%$ have higher education, a fact which supports the hypothesis of an important loss of human capital registered by Romania (fig. 2).

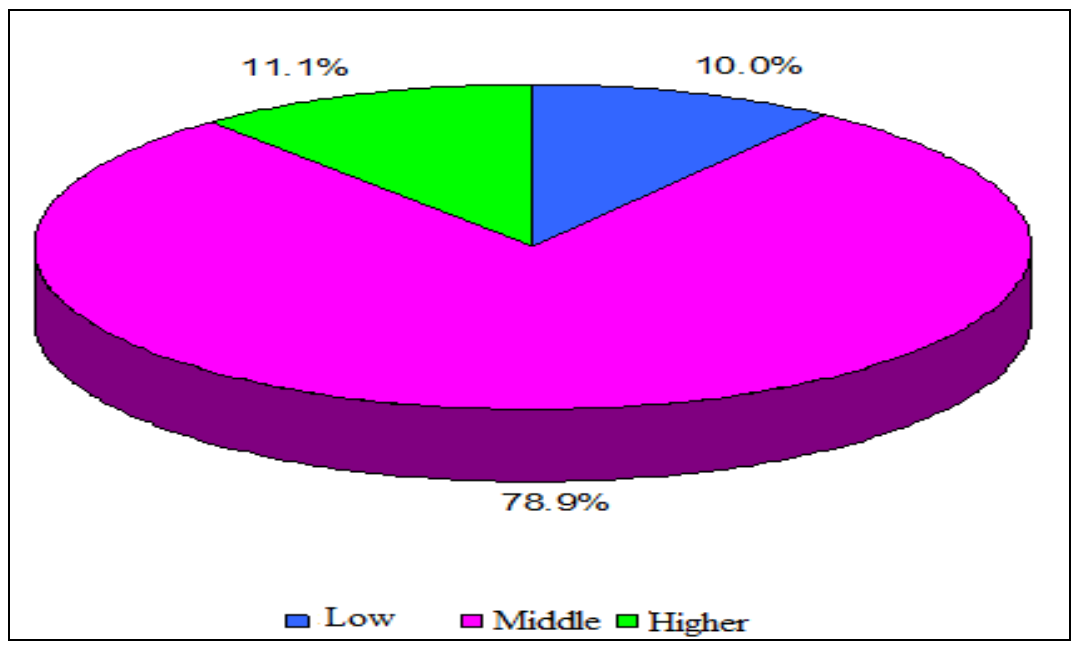

Figure 2: Distribution on educational levels

Regarding marital status, the survey reveals (Fig. 3) that those who are married $(58.5 \%)$ or cohabiting (12.7\%) predominate. This tendency could favour either the settlement in Italy or the return to the origin country. That is why the authors used the marital status (ms) variable in the logistic regression function from SPSS to determine the intensity of the return trend. However, most of the respondents claim that they live in Italy with a partner (62.7\% - Figure 4$)$ and that they are there along with more than 2-3 family members, including children ((76.5\%, Figure 5). 


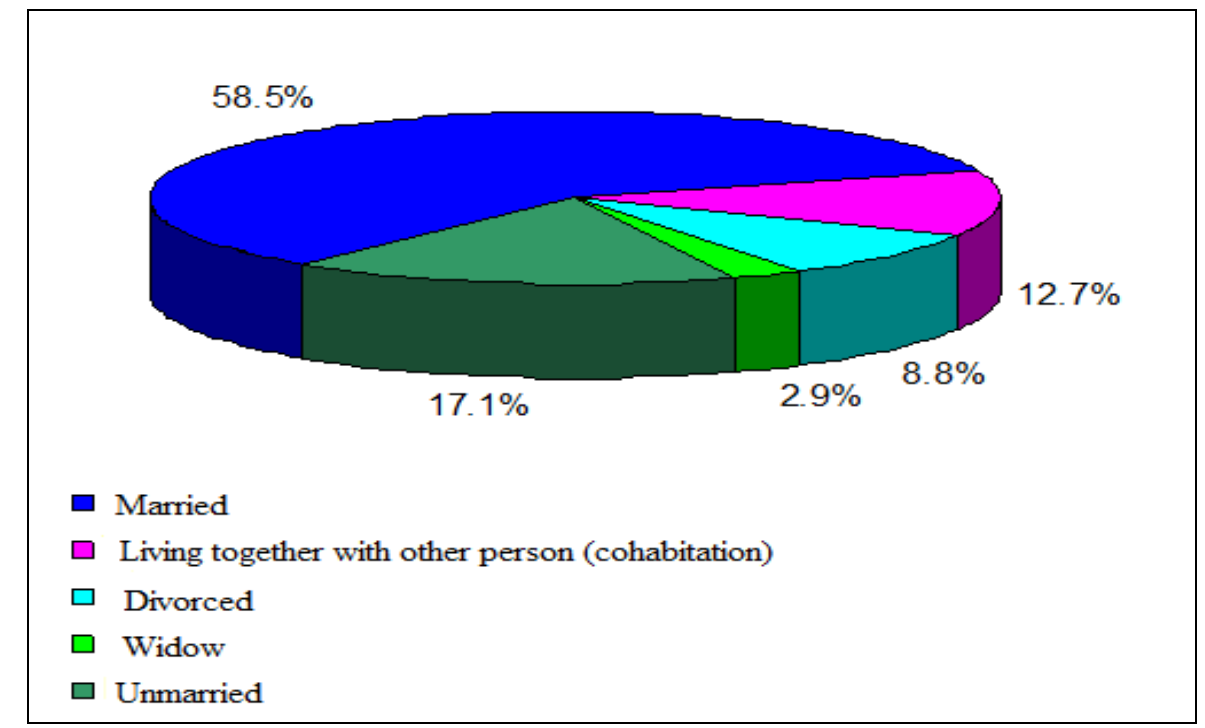

Figure 3: Distribution on marital status (\%)

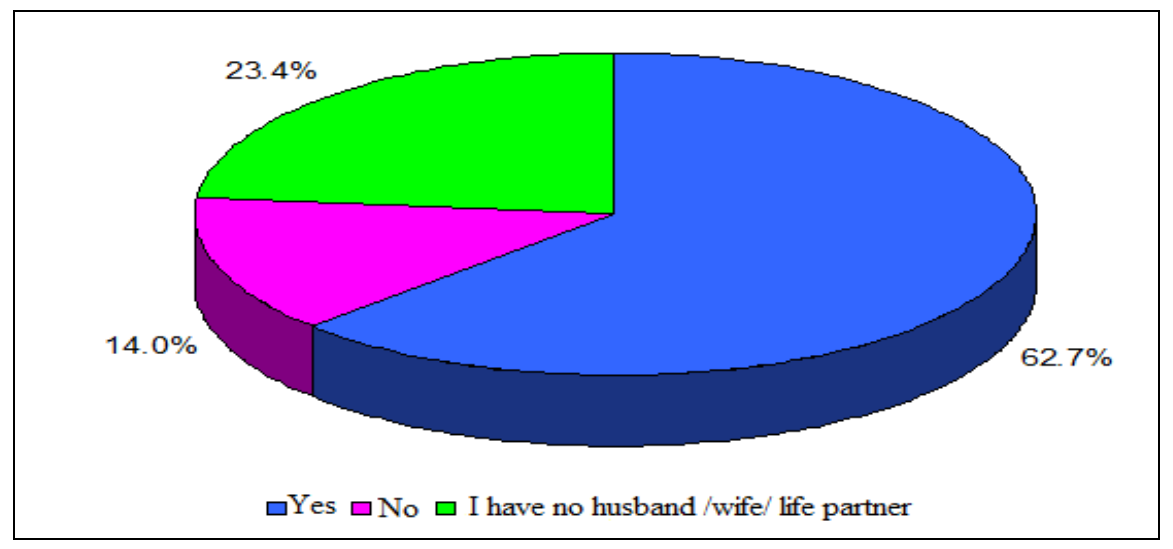

Figure 4 : Answers' distribution on question „Does your partner/wife/husband lives in Italy?"

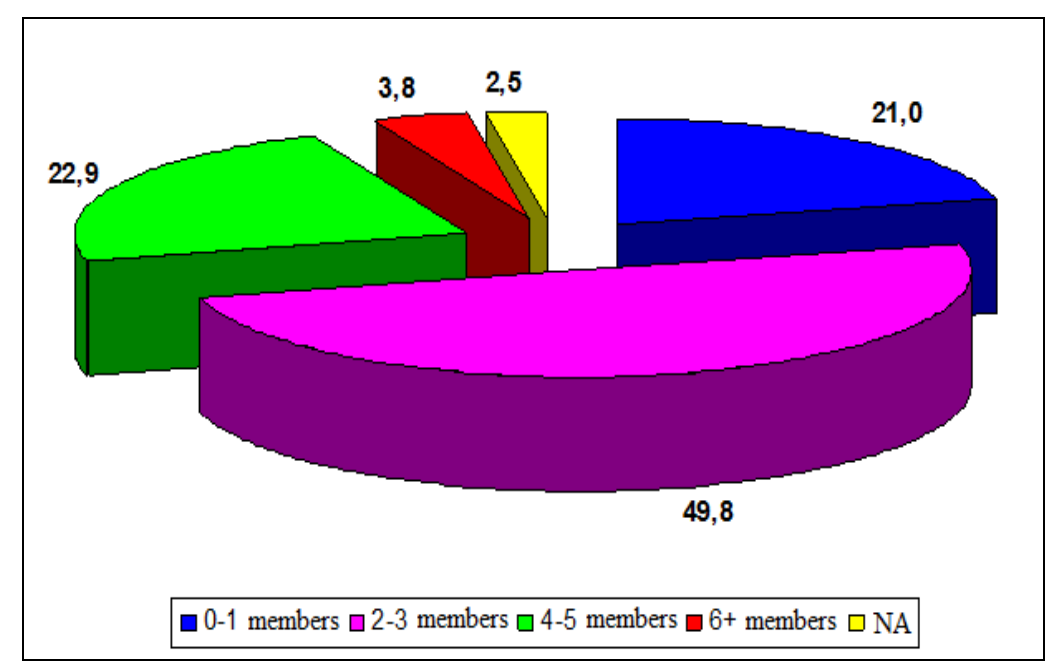

Figure 5: Respondents' distribution after the family members that live in Italy 
The representatives' results in Figures 4 and 5 could support an alternative intention of Romanian immigrants to settle in Italy. An additional argument for such an intent is supported by the fact that almost a quarter of the Romanian immigrants in Italy are older than 10 years. The stabilization of the Romanian immigrants in Italy is proved by the fact that almost a quarter of them are older than ten years (23.8\% went there before 2000, the study was conducted in 2011), as shown in Figure 6. However, the greatest wave of emigration (51.4\%) was recorded in 20002006, during the boom, but prior to the EU accession.

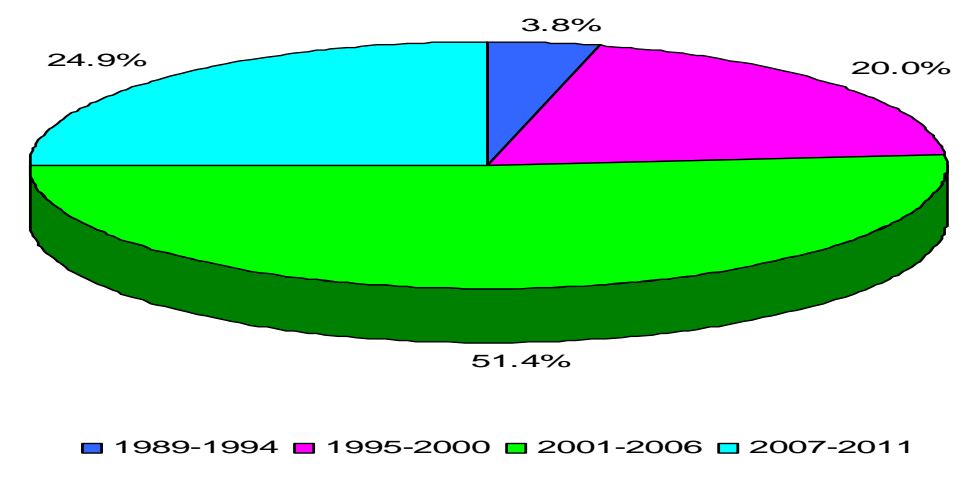

Figure 6: Respondents Distribution after first arrival period

\section{Participation of Romanian emigrants in the labour market in Italy}

In terms of the professional experience accumulated, more than half of the emigrants left Romania from the position of employee. However, $13.8 \%$ of migrants come from students which shows that a significant number of Romanian graduates realize their transition from school to work abroad (Italy) and not in Romania (Figure 7). This distribution of responses shows that unemployment was the main economic motivation for emigration.

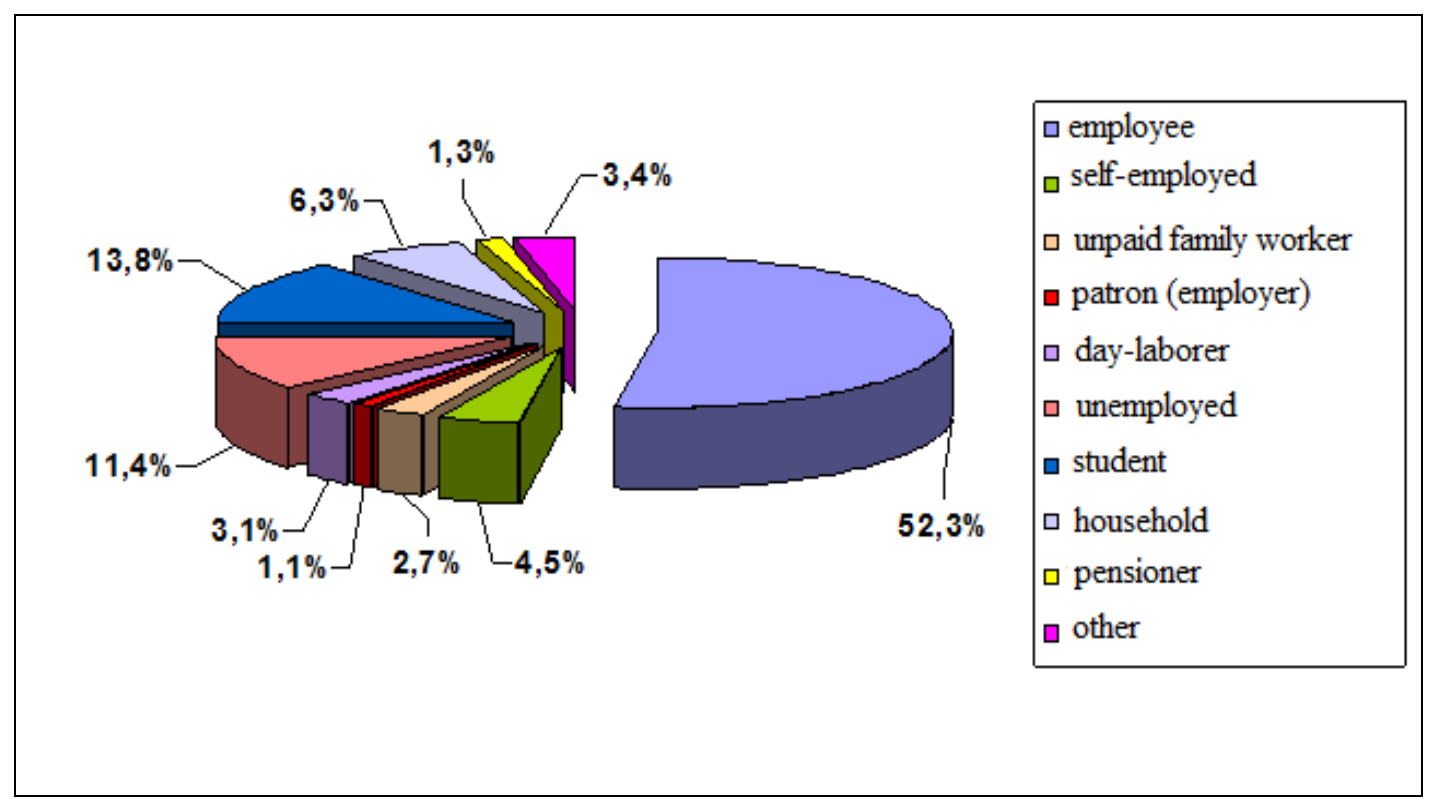

Figure7: Occupational status of respondent before migration 
Occupational distribution by sectors (Fig. 8) shows that most of Romanian immigrants in Italy work in constructions $(15 \%)$, industry $(11.8 \%)$, trade $(8.7 \%)$, tourism and restaurants (5.8\%). However, the majority $(37.1 \%)$ of them say that they are working in various activities ((housekeeping, care person), which does not show a definite occupational status, but rather an attempt to adapt to the local labour market in Italy. These results show that Romanian immigrants in Italy are turning to heavy work $(26.8 \%$ - in construction and industry), or are trying to adapt to different jobs $(37.1 \%)$.

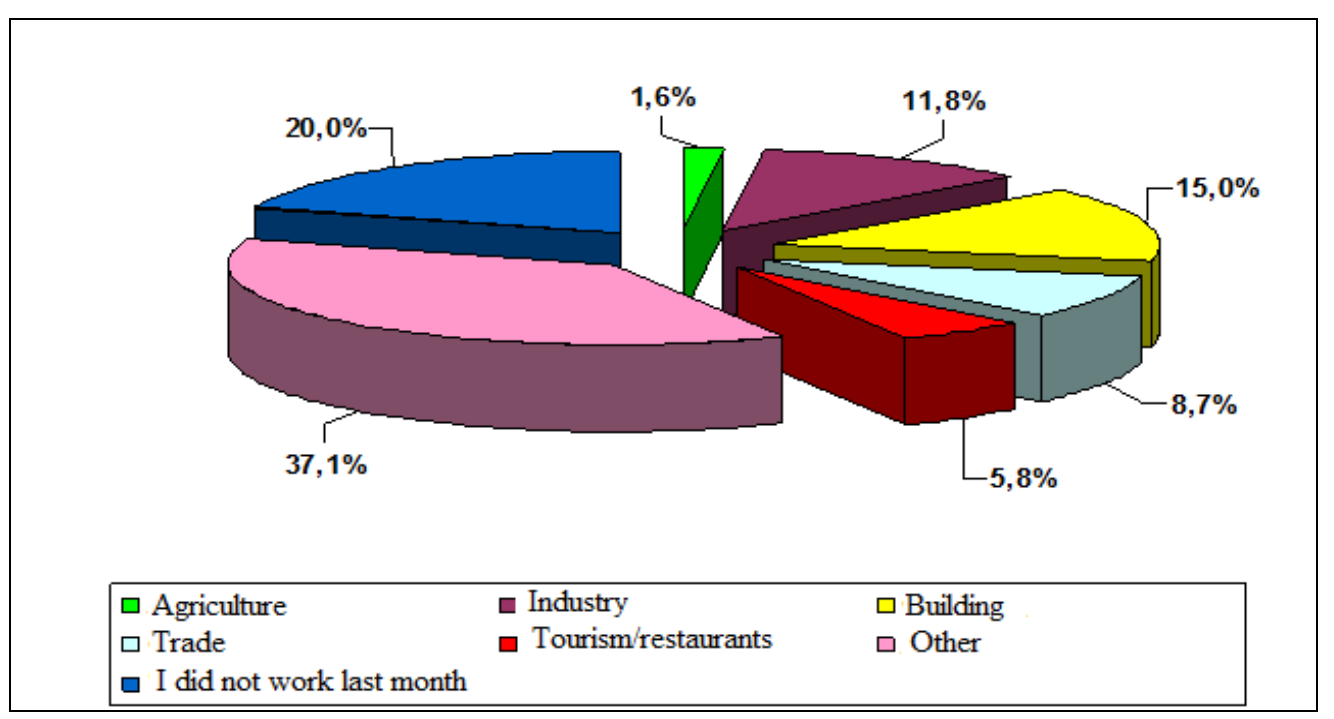

Figure 8: Activity sectors distribution last month

There is some professional inertia of the Romanian emigrants in Italy in the event of returning in the country (Fig. 9). Most preferred would be the building $(80 \%)$, followed by trade (68\%), tourism and restaurants (62\%) and Industry (59\%).
However, this matching of the professional profile may have positive effects in the event of returning in the country, by making use of the experience gained in Italy.

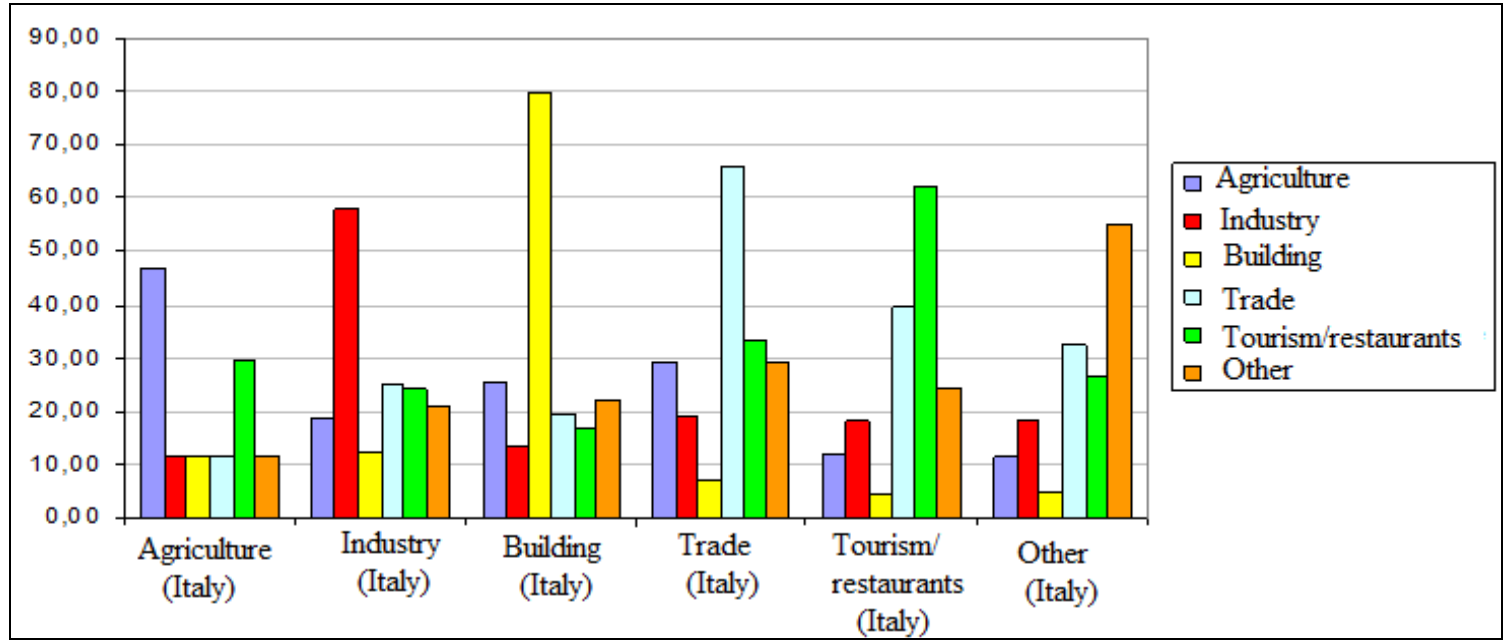

Figure: 9 Distribution of responses on the sector now works in Italy and the sector would return to work in Romania 
As a confirmation of the high degree of integration of Romanian immigrants on the Italian labour market, most of them (59.3\%) participate in the labour market through contractual relationships clearly defined (Fig. 10). In addition $4 \%$ of them work in their field of activity. However, there is a significant part $(18 \%)$ of Romanian immigrants that work without labour contracts, do not work or do not receive unemployment benefits $(13.9 \%)$.

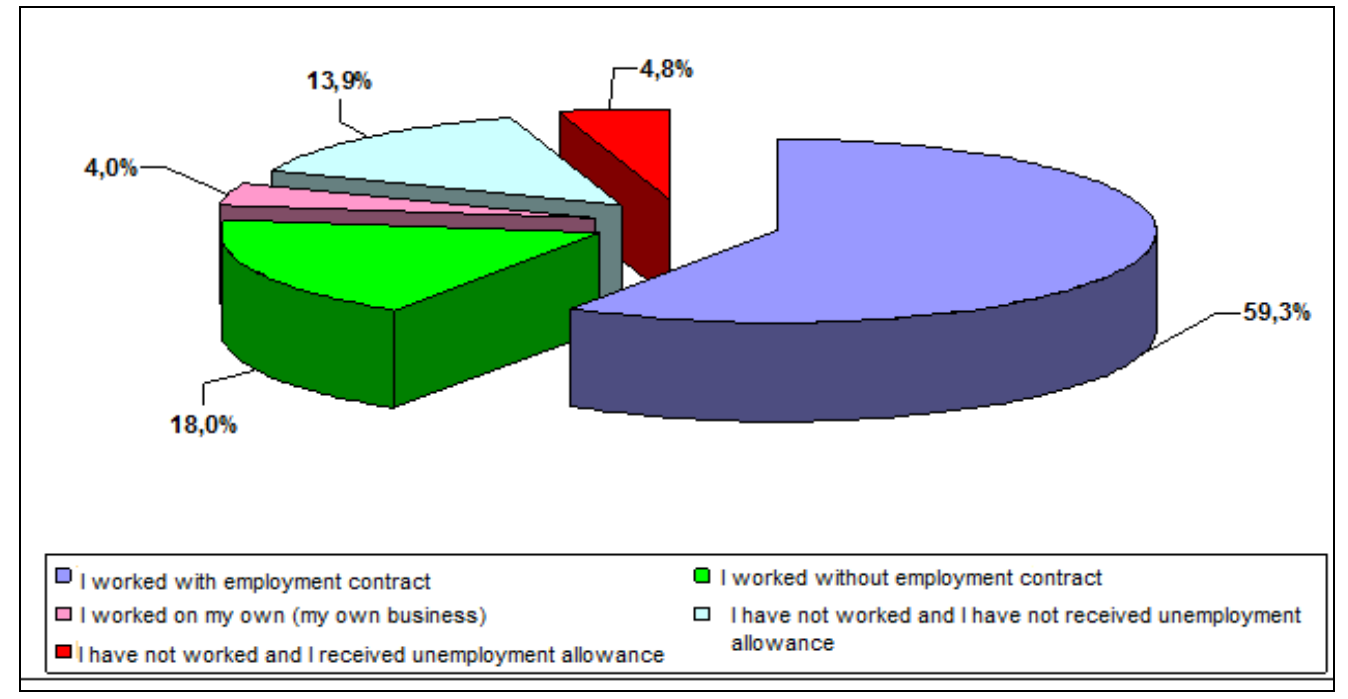

Figure 10: Contractual situation of Romanian migrants on activities

Although most (46.6\%) of Romanian emigrants earn between 500 and 1,000 euros per month (Fig. 11), a third of them $(33,3 \%)$ have incomes between 1,000 to 1,500 euros, and about $10 \%$ have incomes of more than 1,500 euros a month. The wage differential is important given that the average monthly net wage in Romania was 355 euros at that period.

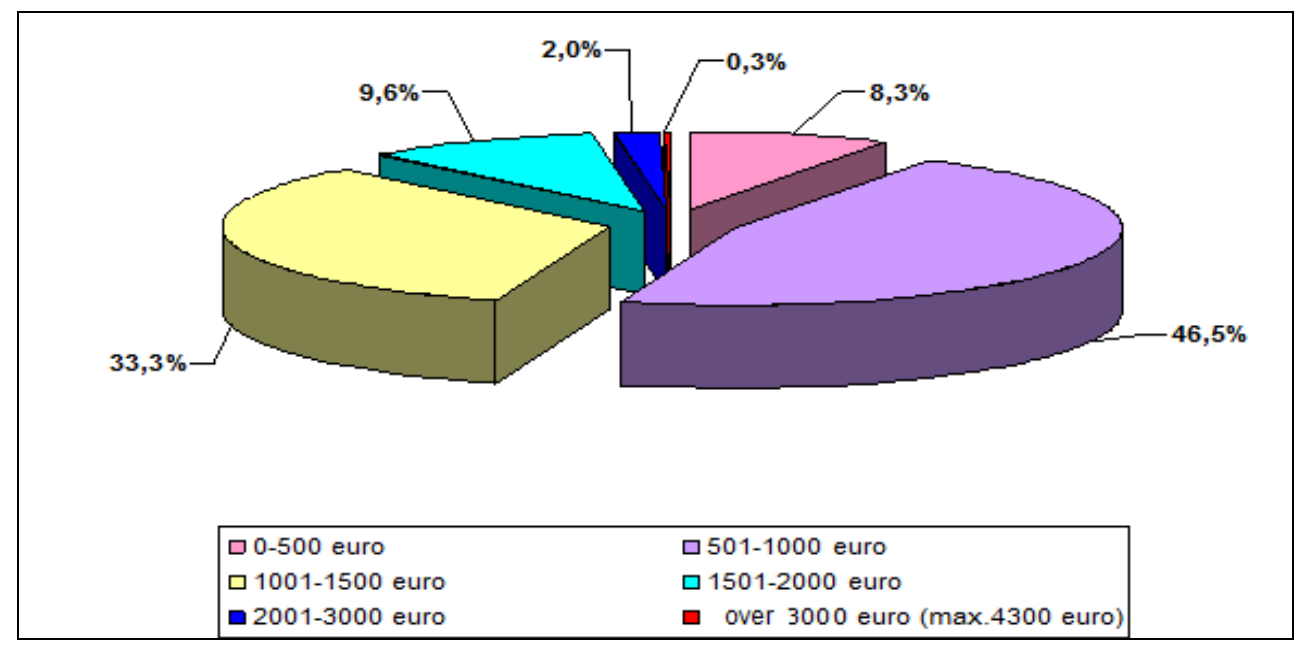

Figure11: Net Revenue last month (Euro) 
Under these circumstances, most of the Romanian emigrants (65.2\%) are declared satisfied and very satisfied in relation to work (Fig.

12).

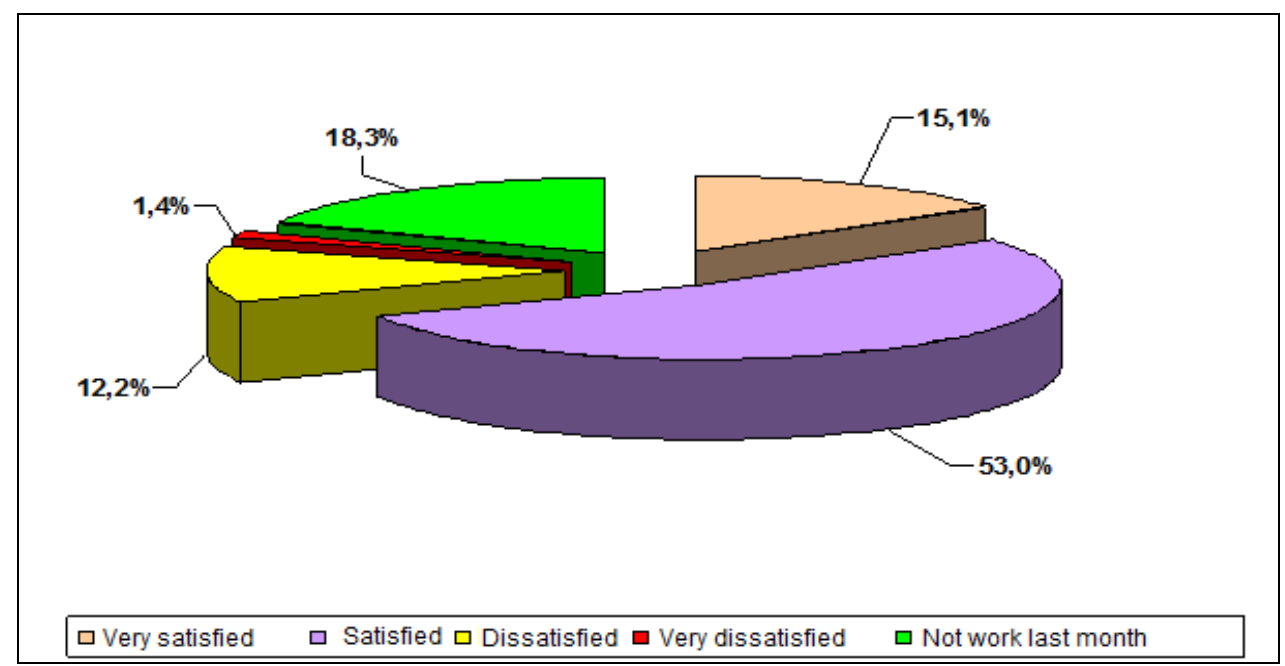

Figure 12: Level of Satisfaction at work last month

Even if they are well placed on the labour market, both in terms of income and salary, Romanians feel strongly discriminated from access to employment (82.6\%), atmosphere at the workplace (80.5\%), and often think of themselves as victims of aggressions (94.8\%).

\section{Estimating the Romanian emigrants' intentions of returning}

Most of Romanian emigrants to Italy often visit home $53 \%$ of respondents said they come every year, and $14.2 \%$ come several times a year), and a large part of them $(19.1 \%)$ at least once in $2-3$ years (Fig. 13. This distribution of responses shows a good connection with the country of origin and could be a solid argument in favour of the possible intention to return to the country of origin.

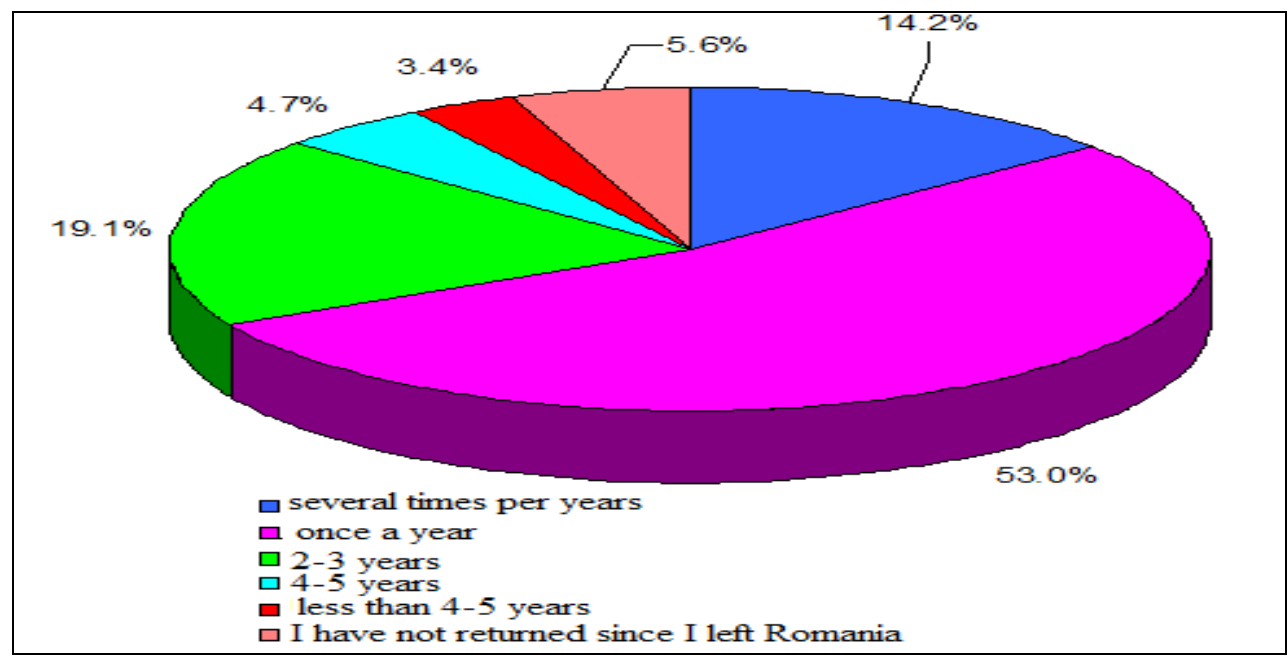

Figure13: Answers' Distribution on visits frequency in Romania 
This situation is well correlated with the fact that most Romanian migrants are young and still close to their relatives in Romania. Moreover, about $62.5 \%$ of those who said they hold real estate in Romania (houses, apartments, and land) are married, and $11.6 \%$ are still married or living in cohabitation. In these circumstances Romanian emigrants are well informed $(57.6 \%$ - good and very good) about the economic situation in the country (Fig. 14).

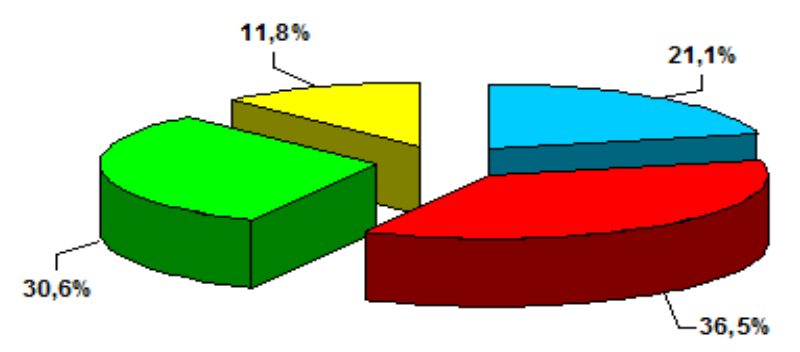

$$
\begin{aligned}
& \square \text { Very well } \\
& \square \text { Well } \\
& \square \text { Little } \\
& \square \text { Very little }
\end{aligned}
$$

Figure 14: Knowledge level of economic situation in Romania

This situation is due to the fact that about a third of respondents have often asked their relatives about how convenient it is to work in Romania, and $29.3 \%$ did so occasionally (Fig. 15). However, most of Romanian emigrants show little interest in the situation in the country of origin (29.8 inquire rarely and $24 \%$ never).

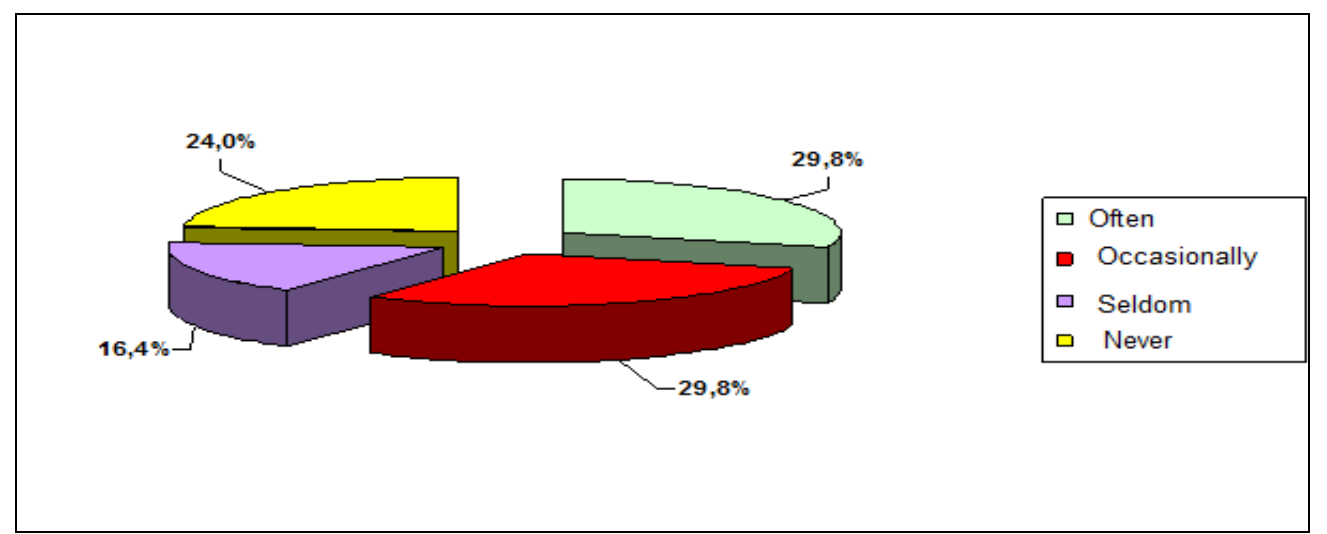

Figure 15: Answers' Distribution of how frequent they asked their relatives of the economic situation in Romania

However, the overwhelming majority (85.8 $\%$.) of respondents think that it is very difficult or hard to find a good job in Romania (Fig. 16). 


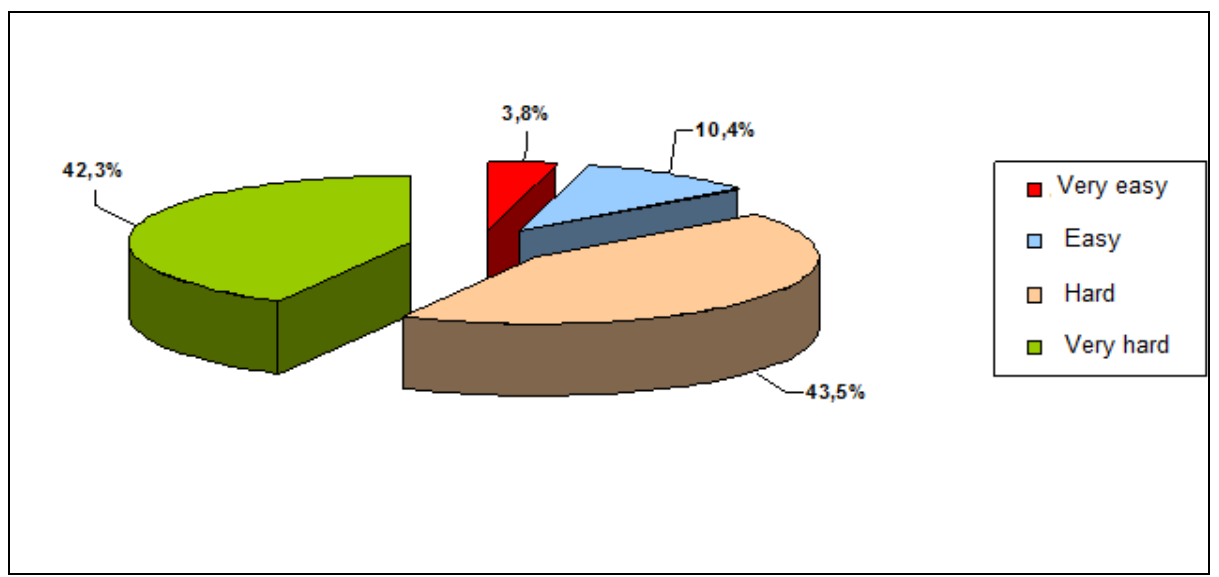

Figure16: Good job position in Romania

Nevertheless, less than half of the Romanians intend to return in the country
(49\%) because of the global economic crisis.

Table 1: Intention of returning in Romania

\begin{tabular}{|ll|}
\hline & Percent \% \\
\hline Yes & 49 \\
No & 28.5 \\
Don't know/no answer & 22.5 \\
\hline
\end{tabular}

If we consider the age distribution of those who have declared their intention to return, we notice the largest share $(68.5 \%)$ is found in the age group over 50 years, the reason being supported by homesickness for those who are preparing to retire (Fig. 17).

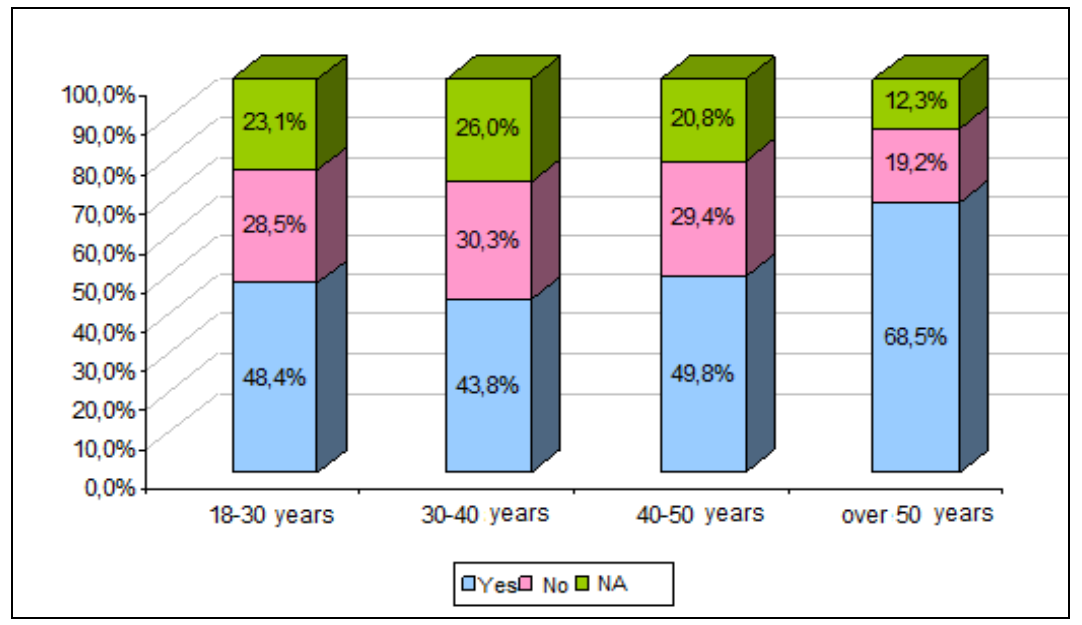

Figure 17: Option of returning to Romania on age distribution

Interestingly, most Romanian emigrants $(42.71 \%)$ did not know or did not respond in relation to the time horizon of the possible return to the country (Table 2). 
Table 2 Answers' frequency for the question „When do you intend to return in Romania?”

\begin{tabular}{|ll|}
\hline & Percent - \% \\
\hline In the next year & 9.7 \\
\hline In the next 2-3 years & 14.2 \\
In the next 4-5 years & 10.7 \\
After more than 5 years & 22.6 \\
Don't know/no answer & 42.8 \\
\hline
\end{tabular}

\section{Testing the motivation intensity of Romanian emigrants to return to the country, or to settle in Italy}

For testing the alternatives between the intentions of Romanian emigrants, the authors used a logistic regression model constructed to identify the variables that may cause the return of Romanian emigrants:

- a binary variable that reflects the emigrants intention to return/ settle in Italy acting as a dependent variable, defined as:

$y=\left\{\begin{array}{l}1, \text { if the migrant intends to retun to Romania } \\ 0, \text { if the migrant do not intend to retun to Romania }\end{array}\right.$

- independent variables whose coefficients are significantly different from zero.

With one exception there are binary variables defined as follows:

- marital status:

$m s=\left\{\begin{array}{l}1, \text { If the respondent has a life partner } \\ 0, \text { If the respondent does not have a life partner }\end{array}\right.$

- minors:

$m c=\left\{\begin{array}{l}1, \text { if the respondent has minor children in Romania } \\ 0, \text { if the respondent does not have minor children in Romania }\end{array}\right.$

- house in Romania:

$h r=\left\{\begin{array}{l}1, \text { if the respondent owns a home in Romania } \\ 0, \text { if the respondent does not own a homein Romania }\end{array}\right.$ -partner in Italy: $p i=\left\{\begin{array}{l}1, \text { if the respondent spouse resides in Italy } \\ 0, \text { if the respondent spouse does not residein Italy }\end{array}\right.$

- house in Italy:

$h i=\{1$, if the respondent owns a homein Italy

$h i=\left\{\begin{array}{l}0, \text { if the respondent does not own a homein Italy }\end{array}\right.$

- job facility:

if $=\left\{\begin{array}{l}1, \text { if the respondentbelieves that he can easily find a job in Romania } \\ 0, \text { if the respondentbelieves that he can not easily find a job in Romania }\end{array}\right.$

Of the 493 observations used to create the model, $28.1 \%$ of the respondents who would not return are correctly classified, while $88.9 \%$ of the respondents who want to return to Romania are correctly classified. Overall, $68 \%$ of respondents are classified correctly.

The only numerical variable whose coefficient is statistically significant is the measuring seniority in Romania and was denoted by $s$.

In the analysis, other variables were introduced such as gender, age, education level, employment status in Italy, residential age in Italy, but the forecast showed that they do not significantly influence respondents' intentions.

Logistic regression tests revealed that there is not a clear intention of Romanian emigrants to settle permanently in Italy. This result can be attributed to unfavourable circumstances created by the global economic crisis (the survey was conducted in 2011), when immigrants were afraid that they would be laid off first due to their residential status. However, it was found that throughout the economic 
crisis, very few Romanian emigrants returned home.
Logistic regression tests seem to indicate a slight mild intention to return to the country (Table 1).

Table 1: Estimation results

\begin{tabular}{|lcccccc|}
\hline Variable & Coefficient & Standard deviation & Wald & df & Sig. & Exp(Coefficient) \\
\hline $\mathrm{ms}$ & 0,549 & 0,221 & 6,189 & 1 & 0,013 & 1,731 \\
$\mathrm{mc}$ & 0,980 & 0,388 & 6,392 & 1 & 0,011 & 2,665 \\
$\mathrm{hr}$ & 0,873 & 0,205 & 18,112 & 1 & 0,000 & 2,394 \\
$\mathrm{pi}$ & $-1,030$ & 0,302 & 11,619 & 1 & 0,001 & 0,357 \\
if & 0,839 & 0,303 & 7,693 & 1 & 0,006 & 2,315 \\
s & 0,032 & 0,013 & 6,378 & 1 & 0,012 & 1,033 \\
c & $-0,542$ & 0,228 & 5,648 & 1 & 0,017 & 0,581 \\
\hline
\end{tabular}

Note:

Nagelkerke R Square $=0.182$

Cox \& Snell R Square $=0.132$

Chi Square 70.094, $\mathrm{df}=6, \mathrm{sig}=0.000$

Chi Square test statistic value is 70.094 with six degrees of freedom. The associated probability is 0.000 indicating that the model is valid. Among the variables included in the regression model whose coefficients' results were significant according to Wald test values and associated probabilities defined as relevant are the following:

- Socio demographic characteristics (marital status, age children in Romania);

- Economic ownership;

- Perceived employment opportunities (in Romania);

- Human capital (work experience).

Socio-demographic variables are captured by coded $\mathrm{ms}$ and $\mathrm{cm}$ and point out that the intention to return to Romania is 1.73 times higher for people who have a spouse (married or are living together with someone in a consensual relation) than the associated single people (divorced, widowed or single), and 2,665 times higher for people who have children in Romania than those who do not have children in Romania, confirming largely the new theory of migration hypothesis (Stark Bloom, 1985) which argues that the decision to migrate does not belong to an individual and therefore should take into account wider social entities such as the family. The latter tends to be risk averse when the income of the whole family is involved. One way to reduce the risk of insufficient income is the migration of one of the family members in order to absorb the benefits of remittances for the family. The migration of a family member is usually temporary because it is either followed by the migration of the whole family, or by the return of the family member. The return intentions may radically change given that Romanian emigrants would be able to bring their whole family in Italy.

The results of the logistic model show that variables that describe the property ownership affect the return of emigrants from Italy as follows:

- The probability of return to the country is 2.4 times higher for people who own a house in Romania than that associated with persons who do not hold such a property. The high explanatory coefficient of this variable shows that having a property in the country is a precaution before emigration.

- The probability of returning to Romania is lower for migrants living in Italy in a house /flat owned by their family than those who live in Italy in a rent or friend's house (coefficient 0.357).

The level of awareness of the labour market in Romania was introduced in the 
model through the encoded variable jf. This variable reflects the respondents' perception about the degree of difficulty associated with finding a job in Romania. The estimation result shows that the probability of returning to the country is 2.3 times higher for those who find it easy and very easy to find a job in Romania, than for those who consider this as being difficult or very difficult.

The numeric variable denoted $s$ expresses the number of years the respondent has worked in Romania which positively influences the likelihood of returning to the country, but with a modest degree (coefficient 1.033). This shows that the human capital variable should be operationalized in the model with other indicators.

In conclusion, the estimation results show that the following categories of emigrants are the most interested in returning to Romania:

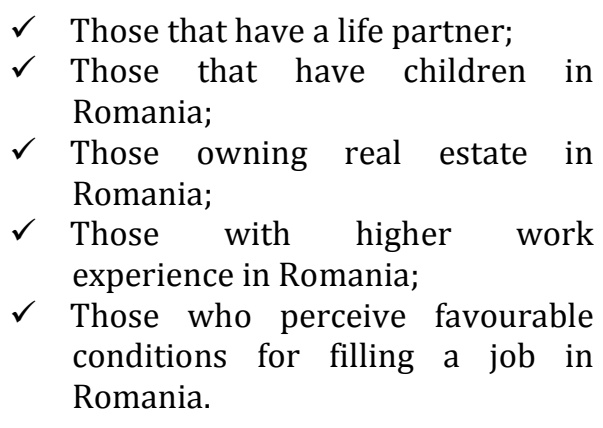

The factors that significantly influence the probability of returning include capital social elements represented by family relations, economic capital accumulated in Romania and perception of existing employment opportunities in Romania. Regardless of the employment status in Italy, the decision to return is determined by the extent to which emigrants anticipate finding a job upon return.

The results of this study support the need to develop a specialized counselling service in employment, since the service will help increase the chances for returning of the Romanian workers. Their return will benefit from the use of their human capital accumulation while working abroad.

\section{Conclusions}

Romanian immigrants in Italy are well integrated into the Italian labour market. However, Romanian immigrants in Italy are heading for heavy work sectors $(26.8 \%$ - in construction and industry), or trying to adapt to different jobs (37.1\%).

Although most of them work legally in Italy, and about a quarter of them are there for more than 10 years, Romanians feel strongly discriminated from access to employment $(82.6 \%)$, atmosphere at the workplace $(80.5 \%)$, or work place aggression (94.8\%).

Factors that retain Romanian immigrants in Italy (age, family integration, income, income satisfaction) seem to be more powerful than those of rejection (discrimination, unfavourable economic situation, links with country of origin family, real estate, homesick).

Immigrants are not aware of the intention of Romanian government to support their return home.

Romanian emigrants have slightly contacted institutions that might support their intention to return to the country.

There are big differences at the level of wages and conditions of work and life; this is a serious obstacle in supporting the intentions of Romanian emigrants to return home.

However, tests carried out using a logistic regression model reveal a slight intention of Romanian emigrants to return to the country. However, given the persistence of the economic crisis these results do not show a strong enough intensity of the Romanian emigrants in order to force the government to implement a set of measures to encourage their return.

The authors believe that further research on the costs and benefits of the Romanian labour force export would be helpful to acquire knowledge for improving decisionmaking on the implementation process of 
any measures to stimulate the return of emigrants.

\section{References}

1. Ailenei, D., Cristescu, A., Huru, D. A regional analysis of Romanian labor and human capital losses, Annual International RSA Conference - Regional Responses and Global Shifts: Actors, Institutions and Organizations - 24-26 May 2010, Pecs, Hungary, ISBN- 978-1-897721-6-0.

2. Bauer, T., Zimmermann, K.F., 1995, Integrating the East: The Labour Market Effects of Immigration, CEPR Discussion Paper Nr. 1235, Londra, www.cepr.org/pubs/dps/DP1235.asp

3. Dustmann, Ch., Weiss, Y., Return Migration: Theory and Empirical Evidence from the UK, (2007), British Journal of Industrial Relations

4. Fawcett, J.T., 1989, Networks, Linkages and Migration Systems, International Migration Review, Vol. 23, Nr. 3, pg. 671680, ISSN 1747-7379

5. Iredale, Robyn, The Migration of Professionals: Theories and Typologies, (2001), International Migration, Volume 39 , Issue 5 , Special Issue 1

6. Jennissen, R., 2007, Causality Chains in the International Migration Systems Approach, Population Research and Policy Review, Vol. 26, pg. 411-436, ISSN 15737829

7. Massey, D.S., Arango, J. et al., Theories of International Migration: A Review and Appraisal, (1993), Population and Development Review 19, No. 3,

8. McConnell, C.R., Brue, S.L., Macpherson, D.A., 2010, Contemporany Labor Economics (ed. 9), McGraw-Hill/Irwin, ISBN 9780070166752

9. Molho, Ian, Theories of migration: a review, (1986), Scottish Journal of Political Economy, Volume 33, Issue 4
10. Oded Stark, O.,Taylor, J. E.,Migration Incentives, Migration Types: The Role of RelativeDeprivation, (1991), The Economic Journal, Vol. 101, No. 408

11. Tiebout, C., 1956, A Pure Theory of Local Expenditures, Journal of Political Economy, Vol. 64, Nr. 5, pg. 416-424, ISSN 1537-534, Volume 45, Issue 2,

\footnotetext{
${ }^{\mathrm{i}}$ This work was supported from the European Social Fund through Sectorial Operational Programme Human Resources Development 2007-2013, project number POSDRU/159/1.5/S/134197, project title "Performance and Excellence in Postdoctoral Research in Romanian Economics Science Domain”
} 